Article

\title{
Index for Characterizing Post-Fire Soil Environments in Temperate Coniferous Forests
}

\author{
Theresa B. Jain ${ }^{1, *}$, David S. Pilliod ${ }^{2}$, Russell T. Graham ${ }^{1}$, Leigh B. Lentile ${ }^{3}$ and \\ Jonathan E. Sandquist ${ }^{1}$
}

1 Rocky Mountain Research Station, USDA Forest Service, Moscow, ID 83843, USA;

E-Mails: rtgraham@fs.fed.us (R.T.G.); jsandquist@fs.fed.us (J.E.S.)

2 U.S. Geological Survey, Forest and Rangeland Ecosystem Science Center, Snake River Field Station, Boise, ID 83706, USA; E-Mail: dpilliod@usgs.gov

3 Department of Forestry and Geology, University of the South, Sewanee, TN 37383, USA;

E-Mail: 1blentil@sewanee.edu

* Author to whom correspondence should be addressed; E-Mail: tjain@ffs.fed.us;

Tel.: +1-208-883-2331; Fax: +1-208-883-2318.

Received: 4 May 2012; in revised form: 8 June 2012 / Accepted: 19 June 2012 /

Published: 6 July 2012

\begin{abstract}
Many scientists and managers have an interest in describing the environment following a fire to understand the effects on soil productivity, vegetation growth, and wildlife habitat, but little research has focused on the scientific rationale for classifying the post-fire environment. We developed an empirically-grounded soil post-fire index (PFI) based on available science and ecological thresholds. Using over 50 literature sources, we identified a minimum of five broad categories of post-fire outcomes: (a) unburned, (b) abundant surface organic matter ( $>85 \%$ surface organic matter), (c) moderate amount of surface organic matter ( $\geq 40$ through $85 \%)$, (d) small amounts of surface organic matter $(<40 \%)$, and (e) absence of surface organic matter (no organic matter left). We then subdivided each broad category on the basis of post-fire mineral soil colors providing a more fine-tuned post-fire soil index. We related each PFI category to characteristics such as soil temperature and duration of heating during fire, and physical, chemical, and biological responses. Classifying or describing post-fire soil conditions consistently will improve interpretations of fire effects research and facilitate communication of potential responses or outcomes (e.g., erosion potential) from fires of varying severities.
\end{abstract}


Keywords: fire effects; fire severity; soil burn severity; post-fire soil productivity; post-fire microbes; post-fire niche

\section{Introduction}

Soils are a forest's foundation. When severely burned by wildfire, potential changes can include reduced soil productivity, increased sedimentation, and altered carbon cycling and sequestration. These changes can impact food production (berries, mushrooms, and wild game), water quality, and aesthetic and recreational use, plus a suite of other ecosystem services that are important to society [1]. Although fire can be viewed as a detrimental disturbance, fire also plays a critical role in regulating and maintaining many forest ecosystems. This dualistic quality of fire has resulted in a long history of research focused on immediate, short-term, and long-term fire behavior and effects.

A fire continuum, from pre-fire conditions to post-fire effects, is a useful conceptual model to understand the different stages in the study of fire ecology [2]. The pre-fire environmental attributes include physical setting, vegetative canopy closure, forest floor depth, and fuel moisture. During a fire, spread rate, flame length, and energy produced (i.e., fire intensity) are used to describe the fire. The direct effects of combustion are often termed first-order fire effects or fire severity and may describe litter consumption and changes in soil color because of soil heating [2-7]. Burn severity does not focus on combustion processes, but simply measures the degree of change (i.e., pre-fire conditions minus post-fire conditions) directly caused by the fire [8,9]. Keeley [10] identifies fire intensity, fire severity, burn severity, ecosystem response, and social impacts (second-order fire effects) as elements of the fire continuum. He does not recognize post-fire conditions as an explicit period along this continuum; rather he places the post-fire environment with other second-order fire effects such as erosion and vegetation recovery. Post-fire conditions - the characteristics of the environment following a fire-affect chemical, biological, and physical aspects of soil responses. In turn, soil responses affect vegetation composition, structure, and successional dynamics through time and across multiple spatial scales [5,11-13]. The post-fire environment is the baseline for a forest's recovery after a fire because it provides an array of habitat niches and post-fire conditions that result in future forest productivity, and species diversity and recovery (both plant and animal) [14-16]. Clearly, because the post-fire environment is an important link between fire severity, burn severity and subsequent response and recovery, it should be considered a separate entity within the fire continuum.

Many scientific disciplines focus on the post-fire environment to understand and predict ecosystem responses to fire. For example, silviculturists and soil scientists observe how post-fire forest soils influence long-term productivity through regeneration establishment, species composition, and forest growth and development [17-19]. Wildlife biologists may investigate how fires impact soils and vegetation because of the post-fire environment effects on habitat quality and availability [20-22], whereas ecologists might consider the role of soils in nutrient cycling and decomposition rates, especially as they relate to carbon sequestration and global carbon cycles [23-25]. Because many of these studies are discipline specific, it is often difficult to integrate results and inferences that could provide a greater relevance, scope, and impact. Thus a more explicit definition and characterization of 
the post-fire environment would open avenues for summarizing and understanding an array of science information across disciplines.

When classification descriptions are provided, they tend to be unique to the particular physical, chemical, or biological processes being studied, and use fire or burn severity as the baseline for ecosystem response. One of the most widely adopted classifications is the Composite Burn Index (CBI), which uses one composite score that includes all forest strata (soils through understory and overstory vegetation) to quantify the degree of change directly caused by a fire. This index has been particularly useful for determining burn severity using remotely sensed imagery [8]. Currently, there is not an integrated and well accepted post-fire index for soils or vegetation. As a result, some scientists and forest managers have used the CBI and dNBR (difference normalized burn ratio) because these data are readily available as a burn severity indicator [8,9]. However, CBI was not designed to characterize the post-fire environment. Moreover, because it is a composite value it is unclear how $\mathrm{CBI}$ values relate to post-fire soil characteristics. To date, no standardized method of quantifying the post-fire environment has been created. Without a standardized method, many scientists develop a classification unique to a particular study or use an inappropriate classification such as in CBI. Consequently, there is a general lack of concise, repeatable, and discernible descriptions of the post-fire environment in the scientific literature.

To meet this need, we developed an empirically-based soil post-fire index (PFI). Our objectives were to: (1) create PFI category break-points using ecologically-based thresholds; (2) relate index categories to post-fire physical, biological, and chemical responses; and (3) validate the indices using field data to ensure feasibility and applicability in the science, management, and policy arenas. Although our index is not an indication of consumption, it can be used to quantify post-fire conditions as a type of severity indicator. More importantly, the soil PFI we developed was the result of a literature compilation and evaluation; thus the index provides a way to integrate results from numerous scientific investigations and fill a critical knowledge gap that will contribute to an ecological understanding of fire and help inform management decisions.

\section{Experimental Section}

To develop and evaluate our soil index, we used a modified version of Pullin and Stewart's [26] three-stage approach: (1) formulate key questions to inform the search, inclusion, and rejection of criteria; (2) conduct a systematic review and synthesis of the relevant literature; and (3) report the resulting indices.

\subsection{Formulating Key Questions}

In stage one, we addressed two primary questions: (1) how is severity or the post-fire environment defined, and (2) what is the empirical rationale for the categories we develop? For the first question, the most critical criterion was whether there was a fire descriptor or classification in the literature. In addition, we identified detailed descriptions (i.e., number of categories, or indicators for selected categories) beyond categories such as low, moderate, high, extreme, or very extreme. To be included in our analysis, the literature also had to address a range of disciplines associated with soils. 
Finally, we searched for indices developed as standalone fire severity classifications that fulfill multiple purposes, or indices specific to a particular subject.

For the second question, addressing the empirical rationale, we examined processes between fire characteristics (temperature and duration) and relationships between post-fire characteristics and a particular response within a given discipline. This evaluation was designed to ensure the soil PFI was aligned with the descriptions and temporal stages in the fire continuum.

\subsection{Reviewing Relevant Literature}

To ensure sufficient scope and relevance to temperate coniferous forests, we reviewed a broad literature base including books, refereed journals, peer-reviewed reports, proceedings, literature reviews, and other synthesis documents. Next we searched online databases (e.g., Google Scholar, Agricola, Web of Science, Ingenta, Forest Science database) using key terms such as fire severity, burn severity, fire intensity and post-fire outcomes or environments. Additional terms included fire AND soil temperatures, fire AND wildlife, prescribed fire, wildfire, forest fires, post-fire, fire and soils, erosion after fire, wildfire AND specific species of amphibians and other soil fauna and flora. To identify relevant internet inaccessible sources, we scanned cited literature in online publications to find published but off-line literature.

\subsection{Synthesis}

When a severity indicator was defined by consumption, we assumed the inverse was the amount left after the fire. For example, if a study reported $40 \%$ of the litter was consumed, we assumed that $60 \%$ remained. Although not ideal, this assumption allowed us to include a larger amount of fire literature in our synthesis. As a result, our PFI is grounded in the available science and management literature, and include thresholds and an ecological rationale for each category.

\subsection{Evaluation}

We used two approaches to evaluate the effectiveness of the index in post-fire assessments. First, we used SAS [27] to post-classify 950 wildfire observations (obtained the following growing season) in mixed conifer forests within three western U.S. climate regimes (cold/wet, warm/dry, and cool/moist). Fires occurred in Colorado (five fires), Idaho (21 fires), and Montana (51 fires) from 2000 through 2003. Second, we used the indices to quantify the post-fire environments for the Cascade Complex of Wildfires (see [28] for a site description) in central Idaho and the Indian and Germaine wildfires in eastern Montana (see [29] for a site description). Circular plots $\left(1.0 \mathrm{~m}^{2}\right)$ were used to characterize the post-fire environment of the Cascade Wildfires and linear transects were used for the Indian and Germaine wildfires. These calculations refined the PFI and provided insight into the feasibility of assigning the PFI using different sampling approaches. 


\section{Results and Discussion}

We found over 50 different post-fire soil classifications in the literature. Many investigators described post-fire soil conditions simply as burned or unburned [30,31], while others focused on select conditions within the range of post-fire outcomes [32-34] (Table 1). The least severely burned categories contained evidence of fire, but with the forest floor intact [35-37]. Moderately severe burned categories described a wide range of conditions from some litter present to all surface organic material consumed. This was particularly true for post-fire assessment protocols $[7,8,38,39]$. The most severely burned categories were often reserved for areas where the forest floor was totally consumed $[3,7,40]$. We found at least five broad categories were necessary to capture the range of described conditions that occur after wildfires (see Table 1).

The proportion of pre-fire surface organic material consumed by fire is a common indicator for defining post-fire soil burn categories [7-9]. Surface organic materials include litter (e.g., leaves, sticks, needles), fermentation layers (e.g., decaying litter, root mats), humus (organic material with unrecognizable plant parts), and brown cubical rotten wood with decomposed material sometimes referred to as "duff" [18]. In general, a burned site is more likely to support vegetation if some surface organic materials are present after a fire [41], but the post-fire amounts and disposition are highly variable $[3,5,9,42,43]$. Wildfires, and more often prescribed fires, typically do not burn organic materials (horizons) uniformly $[12,44]$. For example, humus often burns along with litter, but in some cases it will burn and leave the litter scorched and intact. Alternatively, some organic surface may burn while other places are left unburned or barely scorched. Because of the variability and inherent difficulty identifying these surface organic materials after a fire (noted in our field validation), we did not separate these materials. Rather, the soil PFI categories represent the abundance of surface organic material (including duff) remaining after the fire, which promotes consistency and reduces the chance for human error when using the PFI.

Mineral soil color, which is generally related to heat residence times and achieved temperatures, is another common post-fire indicator [6,45-47] (Table 1). The mineral soil color is commonly classified as black (semi-combusted organic material), gray or white (ash from organic material), and orange (change in physical structure and lack of organic material) $[7,43,48]$. Post-fire soil color depends on the amount and type of pre-fire vegetation and surface organic material, their respective moisture contents, and weather (e.g., wind speed, relative humidity, air temperature) during a fire. For example, on grasslands, small amounts of dry litter can burn quickly and may leave no ash or any sign of char on mineral soil $[5,43,46]$. In contrast, post-fire orange colored soils occur when large amounts of woody debris (e.g., 10-20 Mg $\cdot \mathrm{ha}^{-1}$ ) or deep duff layers (e.g., $>20 \mathrm{~cm}$ ) burn for long time periods $[3,5,43]$. 
Table 1. Literature compilation of categorizations. We used this compilation to quantify soils after a fire with resulting soil post-fire index (PFI) categories shown on the last line of this table (Table 2 describes the PFI indicators). Different colors (i.e., green to red) indicate the defined categories included in the publication while non-shaded cells (---) denote an outcome that was not included. Post-fire characteristics most noted had two primary indicators. First, the amount of surface organics (e.g., litter, humus, rotten wood) present, expressed as abundant, present, or absent on the forest floor. Second, whether the litter is scorched (S) and the state of the exposed mineral soil: unburned (U), blackened from combustion (B), gray/white (G) from ash, or orange (O) from mineralogical changes.

\begin{tabular}{|c|c|c|c|c|c|c|c|c|c|c|c|c|c|c|}
\hline \multirow[b]{4}{*}{ Reference } & \multirow[b]{4}{*}{ Application } & \multirow{4}{*}{$\begin{array}{c}\text { Number } \\
\text { of } \\
\text { categories }\end{array}$} & \multicolumn{12}{|c|}{ Post-fire characteristic } \\
\hline & & & \multirow[b]{3}{*}{ Unburned } & \multicolumn{11}{|c|}{ Forest floor } \\
\hline & & & & \multicolumn{4}{|c|}{ Abundant } & \multicolumn{3}{|c|}{ Present } & \multicolumn{4}{|c|}{ Absent } \\
\hline & & & & $\mathbf{S}$ & $\mathbf{U}$ & B & G & $\mathbf{U}$ & B & G & $\mathbf{U}$ & B & $\mathbf{G}$ & $\mathbf{O}$ \\
\hline \multicolumn{15}{|c|}{ Physical effects } \\
\hline [9] & Values at risk & 3 & --- & & & & & & & & & & & \\
\hline [49] & Water infiltration & 2 & --- & & & & & & & & & & & \\
\hline [50] & Water repellency & 3 & & & & & & & & & & & & \\
\hline$[51-53]$ & Erosion & 2 & --- & & & & & & & & & & & \\
\hline [54] & Erosion & 3 & --- & & & & & & & & & & & \\
\hline$[56]$ & Organic matter & 2 & & & & & & & & & & & & \\
\hline [57] & Water repellency & 2 & --- & & & & & & & & & & & \\
\hline [58] & Physical & 4 & --- & & --- & --- & --- & --- & --- & --- & & & & \\
\hline \multicolumn{15}{|c|}{ Chemical effects } \\
\hline$[31,40]$ & Nutrient dynamics & 2 & & & & & & & & & & & & \\
\hline [34] & Chemistry & 2 & --- & & & & & & & & & & & \\
\hline [59] & Mineralogy & 2 & & --- & --- & --- & --- & --- & --- & --- & \begin{tabular}{|l|}
--- \\
\end{tabular} & --- & & --- \\
\hline [60] & Nutrient dynamics & 2 & & --- & --- & --- & --- & --- & --- & --- & --- & & & \\
\hline [61] & Nitrogen & 2 & & $-{ }_{---}$ & \begin{tabular}{|l|}
--- \\
\end{tabular} & --- & \begin{tabular}{|l|}
-- \\
\end{tabular} & \begin{tabular}{|l|}
-- \\
-
\end{tabular} & \begin{tabular}{|l|}
--- \\
\end{tabular} & --- & & & & \\
\hline$[30,62]$ & Nitrogen & 2 & & & & & & & & & & & & \\
\hline [63] & Chemistry & 3 & & --- & --- & --- & --- & & & & & & & \\
\hline [64] & Nitrogen fixation & 3 & & --- & --- & --- & -- & --- & --- & & --- & --- & & --- \\
\hline \multicolumn{15}{|c|}{ Biological effects } \\
\hline [32] & Biological review & 5 & & & & & & & & & --- & --- & & --- \\
\hline [33] & Shrubs & 2 & --- & & & & & -- & --- & --- & \begin{tabular}{|l|}
-- \\
\end{tabular} & & & \\
\hline [36] & \begin{tabular}{|l|} 
Seed survival \\
\end{tabular} & 3 & --- & & & & & -- & \begin{tabular}{|c|}
-- \\
\end{tabular} & --- & --- & & & \\
\hline [45] & Seed survival & 5 & --- & & & & & & & & & & & --- \\
\hline$[65,66]$ & Fungi & 2 & & & & & & & & & & & & \\
\hline [67-69] & Vegetation & 3 & --- & & & & & & & & & & & \\
\hline [70] & Vegetation & 4 & & & & & & & & & & & & \\
\hline \multirow[b]{2}{*}{ Soil PFI } & \multirow[b]{2}{*}{ Integrated Index } & 5 & 0.0 & 1.0 & \multicolumn{3}{|c|}{2.0} & \multicolumn{3}{|c|}{3.0} & \multicolumn{4}{|c|}{4.0} \\
\hline & & 12 & 0.0 & 1.0 & 2.1 & 2.2 & 2.3 & 3.1 & 3.2 & 3.3 & 4.1 & 4.2 & 4.3 & 4.4 \\
\hline
\end{tabular}


Table 1. Cont.

\begin{tabular}{|c|c|c|c|c|c|c|c|c|c|c|c|c|c|c|}
\hline \multirow[b]{4}{*}{ Reference } & \multirow[b]{4}{*}{ Application } & \multirow{4}{*}{$\begin{array}{c}\text { Number } \\
\text { of } \\
\text { categories } \\
\end{array}$} & \multicolumn{12}{|c|}{ Post-fire characteristic } \\
\hline & & & \multirow[b]{3}{*}{ Unburned } & \multicolumn{11}{|c|}{ Forest floor } \\
\hline & & & & \multicolumn{4}{|c|}{ Abundant } & \multicolumn{3}{|c|}{ Present } & \multicolumn{4}{|c|}{ Absent } \\
\hline & & & & $\mathrm{S}$ & $\mathbf{U}$ & $\mathbf{B}$ & G & $\mathbf{U}$ & B & G & $\mathbf{U}$ & B & $\mathbf{G}$ & $\mathbf{O}$ \\
\hline \multicolumn{15}{|c|}{ Biological effects } \\
\hline [71] & Microbes & 2 & & --- & --- & ---1 & --- & --- & --- & --- & & & & \\
\hline [72] & Vegetation & 3 & --- & & & & & & & & & & & \\
\hline [73] & Forest structure & 4 & & & & & & & & & & & & \\
\hline [74] & Arthropods & 2 & & & & & & & & & --- & --- & -- & --- \\
\hline [75] & Regeneration & 3 & --- & & & & & & & & & & & \\
\hline [76] & Seed survival & 3 & & & & & & & & & & & & \\
\hline \multicolumn{15}{|c|}{ Assessment } \\
\hline [7] & Prescribed fire & 4 & & & & & & & & & & & & \\
\hline [8] & Remote sensing & 4 & & & & & & & & & & & & \\
\hline [35] & Remote sensing & 3 & --- & & & & & & & & & & & \\
\hline [37] & Physical setting & 3 & --- & & & & & & & & & & & \\
\hline [38] & Remote sensing & 4 & & & & & & & & & & & & -- \\
\hline$[39,77]$ & Monitoring & 5 & & & & & & & & & & & & \\
\hline [39] (grasslands) & Monitoring & 5 & & & & & & & & --- & & & & --- \\
\hline$[55]$ & Monitoring & 5 & & & & & & & & & & & & \\
\hline [78] & Monitoring & 3 & --- & & & & & & & & & & & \\
\hline [79] & Remote sensing & 5 & --- & & & & & & & & & & & \\
\hline \multicolumn{15}{|c|}{ Literature review } \\
\hline [3] & Soil effects & 3 & \begin{tabular}{|c|}
--- \\
\end{tabular} & & & & & & & & & & & \\
\hline [5] (forests) & Soil effects & 3 & --- & & & & & & & & & & & \\
\hline [5] (grassland) & Soil effects & 3 & --- & & & & & & & & & & & -- \\
\hline$[80]$ & Fire ecology & 5 & & & & & & & & & & & & \\
\hline \multirow[b]{2}{*}{ Soil PFI } & \multirow[b]{2}{*}{ Integrated Index } & 5 & 0.0 & 1.0 & \multicolumn{3}{|c|}{2.0} & \multicolumn{3}{|c|}{3.0} & \multicolumn{4}{|c|}{4.0} \\
\hline & & 12 & 0.0 & 1.0 & 2.1 & 2.2 & 2.3 & 3.1 & 3.2 & 3.3 & 4.1 & 4.2 & 4.3 & 4.4 \\
\hline
\end{tabular}

Underlying rock may be exposed when surface organic material is consumed during a fire. Because this is site specific and not necessarily common, we did not include exposed rock in the PFI. We do recommend it as an auxiliary indicator where rock is commonly found directly below surface organic material. We also occasionally found sites or plots in areas of inorganic substances (e.g., boulders, rock, pavement, or roads) that could not burn [39,77]. If a site was truly without combustible material, we classified it as unburned. We did not include post-fire needle fall because we focused on what a fire leaves on the soil and not what is added to the soil after combustion. Post-fire needle fall is an important mitigating component of the post-fire environment because it influences soil erosion potential [49] and seed germination [45]. Therefore, we suggest adding it as an auxiliary indicator to address particular management and research objectives.

From the literature compilation we developed a key with five broad PFI categories: unburned (0.0) and categories 1.0 to 4.0 based on the abundance of post-fire surface organic 
matter (Table 2). We then partitioned the categories by soil color. Although several publications note that lightly burned areas sometimes had surface organic material intact, there were no defined thresholds. We initially considered $100 \%$ surface organic material as a threshold for category 1.0 , but could not find an ecological rationale for this value. Page-Dumroese et al. [23] synthesized current soil quality standards and guidelines and reported a threshold of $\leq 85 \%$ organic cover as potentially affecting soil productivity and sustainability. Although their threshold was not intended to characterize post-fire outcomes, we used it as a conservative value for category 1.0 when little or no fire effect on the soil was evident. Category 1.0 does not include a secondary indicator of char or mineral soil color because these areas, although blackened by the fire, are still intact and needles and other organic material are recognizable and mineral soil exposure, composition, or color is often unchanged.

Table 2. Soil post-fire index (PFI) classification key. Developed from the literature synthesis, the key is nested using two criteria: (1) the abundance of surface organic matter to create broad categories, and (2) mineral soil color to partition the broad categories. Surface organic cover can include litter, humus, rotten wood, and in some cases a root mat. As with any key, one begins by evaluating the site based on 1a or 1b. If $1 \mathrm{~b}$ is "yes" then surface organic cover is evaluated using ocular or grid sampling estimates. For example, if surface organic cover is $<40 \%$ (3b) then this broad category can be dissected based on mineral soil color (5a-5d). If the plurality of the soil is charred orange (5d) then the resulting PFI category is 3.4. Although a plurality of orange colored soil is rare within categories 2.0 or 3.0 (it did not occur in our literature compilation), we included it to cover all potential outcomes.

Soil characteristics

1a No evidence of a recent fire

1b Evidence of recent fire

2a Surface organic cover $\geq 85 \%$

$2 b$ Surface organic cover $<85 \%$

3a Forest floor surface organic cover $\geq 40 \%$ and mineral soil appearance has a plurality of:

4a unburned mineral soil

4b black charred mineral soil

$4 \mathrm{c}$ gray/white charred mineral soil

$4 \mathrm{~d}$ orange charred mineral soil

$3 \mathrm{~b}$ Surface organic cover $<40 \%$ and mineral soil appearance has a plurality of:

5a unburned mineral soil

$5 b$ black charred mineral soil

5c gray/white charred mineral soil

$5 \mathrm{~d}$ orange charred mineral soil

3c (Forest floor absent) No surface organic matter left and mineral soil appearance has a plurality of:

6a unburned mineral soil

$6 \mathrm{~b}$ black charred mineral soil 
The next threshold (categories 2.0 and 3.0) is for areas that have between $0 \%$ and $85 \%$ surface organic material. Literature on post-fire erosion and hydrophobic soils identifies thresholds across a range of surface organic material percentages (30\%, [50]; 40\%, [51]; 45\%, [54]; 50\%, [52]) from which we selected the median (40\%) to divide the categories where 2.0 is $40-85 \%$ and 3.0 is less than $40 \%$. We further categorized them by mineral soil char color using a decimal. For example, within category 2.0 (40\% to $85 \%$ organic matter), unburned soil is 2.1 and areas with a plurality of black char, gray or white ash, or orange-colored soil are 2.2, 2.3, and 2.4, respectively. We use the term "plurality" to partition the categories and avoid focusing on minute amounts of char color. The method of using plurality has precedence in ecological applications (e.g., [81]), and offers consistency for identifying and interpreting categories when multiple soil colors are present.

\subsection{Relating the PFI to Fire Severity}

To determine how PFI category indicators are related to fire behavior characteristics, we used available soil heating literature to identify corresponding temperatures (Table 3). Although unburned soils (PFI category 0.0) are not a function of a fire effect, they occur within a fire perimeter. Therefore, we searched the literature for unburned surface temperatures. Haig et al. [82] measured summertime diurnal temperatures on forest soil surfaces in the Northern Rocky Mountains and found they ranged from $40{ }^{\circ} \mathrm{C}$ to $55{ }^{\circ} \mathrm{C}$. Cochran [83] identified temperature ranges from $5{ }^{\circ} \mathrm{C}$ to $50{ }^{\circ} \mathrm{C}$ on the surface of clay soils with litter, and $17{ }^{\circ} \mathrm{C}$ to $22{ }^{\circ} \mathrm{C}$ at the litter and soil interface. Using this information, we assumed that unburned surface temperatures tend to vary from $5{ }^{\circ} \mathrm{C}$ to $55^{\circ} \mathrm{C}$.

Table 3. Duration and associated temperatures required to influence soil properties. These attributes occur when the fire is actually burning (i.e., the fire-environment). Duration is estimated from literature sources. Minimum duration of temperature during field experiments came from [5] for chaparral, [84] for grasslands, and [85] and [86] for forests. The corresponding PFI category is shown for each fire behavior characteristic.

\begin{tabular}{|c|c|c|c|c|c|c|c|}
\hline \multirow[t]{2}{*}{ Indicator characteristics } & \multirow{2}{*}{$\begin{array}{c}\text { Temperature } \\
\text { range }\left({ }^{\circ} \mathrm{C}\right)\end{array}$} & \multirow[t]{2}{*}{ Duration } & \multicolumn{4}{|c|}{$\begin{array}{c}\text { Soil PFI category by } \\
\text { forest floor cover }(\%)\end{array}$} & \multirow[t]{2}{*}{ Reference } \\
\hline & & & $>85$ & 40-85 & $<45$ & $\mathbf{0}$ & \\
\hline & \multicolumn{7}{|c|}{ Forest floor surface } \\
\hline Unburned & $40-55$ & Daily fluctuations & 0.0 & & & & {$[82]$} \\
\hline Unburned & $17-22$ & Daily fluctuations & 0.0 & & & & {$[83]$} \\
\hline \multirow[t]{2}{*}{ Charring of litter } & $177-200$ & Seconds to minutes & 1.0 & 2.0 & 3.0 & 4.0 & {$[45,46]$} \\
\hline & \multicolumn{7}{|c|}{$\begin{array}{r}\text { Mineral soil surface } \\
\end{array}$} \\
\hline Unburned & $30-55$ & Daily fluctuations & & 2.1 & 3.1 & 4.1 & {$[82]$} \\
\hline Unburned & $5-55$ & Daily fluctuations & & 2.1 & 3.1 & 4.1 & {$[83]$} \\
\hline Black ash & $200-300$ & $>5$ minutes & & 2.2 & 3.2 & 4.2 & {$[6,45,46,87]$} \\
\hline Gray to white ash & $300-400$ & $\begin{array}{l}5 \text { minutes to } \\
1 \text { hour }\end{array}$ & & 2.3 & 3.3 & 4.3 & {$[3,45,88]$} \\
\hline Orange & $\begin{array}{c}400-500 \\
>500\end{array}$ & $\begin{array}{l}1 \text { hour } \\
\text { Seconds }\end{array}$ & & 2.4 & 3.4 & 4.4 & {$[3,89]$} \\
\hline Hydrophobicity intensified & $\begin{array}{l}204-260 \\
177-204\end{array}$ & $\begin{array}{l}15 \text { minutes } \\
>15 \text { minutes } \\
\end{array}$ & & & 3.2 & 4.2 & {$[90]$} \\
\hline
\end{tabular}


Table 3. Cont.

\begin{tabular}{|c|c|c|c|c|c|c|c|}
\hline \multirow[t]{2}{*}{ Indicator characteristics } & \multirow{2}{*}{$\begin{array}{l}\text { Temperature } \\
\text { range }\left({ }^{\circ} \mathrm{C}\right)\end{array}$} & \multirow{2}{*}{ Duration } & \multicolumn{4}{|c|}{$\begin{array}{c}\text { Soil PFI category by } \\
\text { forest floor cover (\%) }\end{array}$} & \multirow[t]{2}{*}{ Reference } \\
\hline & & & $>85$ & $40-85$ & $<45$ & $\mathbf{0}$ & \\
\hline & \multicolumn{7}{|c|}{ Mineral soil surface } \\
\hline Hydrophobicity reduced & $>288$ & $>5$ minutes & & & 3.3 & 4.3 & [90] \\
\hline \multirow{2}{*}{ Combustion of organics } & \multirow{2}{*}{$200-450$} & \multirow{2}{*}{$>5$ minutes } & & 2.2 & 3.2 & 4.2 & \multirow{2}{*}[48]{} \\
\hline & & & & 2.3 & 3.3 & 4.3 & \\
\hline Laterization process begins & $>450$ & $+1 \mathrm{hr}$ & & & 3.4 & 4.4 & [48] \\
\hline Structure stability decreases & $200-450$ & Minutes & & & 3.4 & 4.4 & [91] \\
\hline Mineralogical changes & $550-600$ & $>12$ minutes & & & 3.4 & 4.4 & {$[48,59,88,91]$} \\
\hline
\end{tabular}

PFI category 1.0 includes areas with scorched surface organic material and up to $15 \%$ of the mineral soil exposed (Table 3). Temperatures from $95{ }^{\circ} \mathrm{C}$ to $177{ }^{\circ} \mathrm{C}$ create charred litter and areas where mineral soil is exposed could have had temperatures reaching $300{ }^{\circ} \mathrm{C}$ during combustion $[6,45,46,87]$. Therefore, diverse (unburned to charred) areas within a fire's perimeter assigned category 1.0 could have surface temperatures ranging from $5{ }^{\circ} \mathrm{C}$ to $300{ }^{\circ} \mathrm{C}$ during combustion.

Categories 2.1-2.3 have a range of organic material cover and mineral soil char colors. These conditions indicate variable soil temperatures and fire duration. Temperatures could range from $5{ }^{\circ} \mathrm{C}$ to $300{ }^{\circ} \mathrm{C}$ at the organic surface, with up to five-minute residence times. If large, dry, and dead downed wood $(>7.5 \mathrm{~cm})$ was present, temperatures $\left(300{ }^{\circ} \mathrm{C}\right.$ to $\left.400{ }^{\circ} \mathrm{C}\right)$ may be sustained for hours, resulting in gray or white ash on the soil surface (PFI category 2.3) $[6,45,46]$. Similar temperatures could occur in PFI category 3.1-3.4 areas, but their distribution would be highly variable, with some exceeding $300{ }^{\circ} \mathrm{C}$. Burned areas described by category 3.4 would have experienced temperatures exceeding $400{ }^{\circ} \mathrm{C}$ with long durations (1 hour minimum) [6,47]. Because categories 4.1-4.4 areas do not have remaining surface organic material, minimum temperatures were approximately $200{ }^{\circ} \mathrm{C}[6,45,46,87]$. Category 4.4 areas would likely have minimum temperatures of $400{ }^{\circ} \mathrm{C}$, and in places with orange soil present, temperatures may have exceeded $500{ }^{\circ} \mathrm{C}$ for an hour or more $[6,47,92]$.

For grass and forest mosaics, where fires typically spread rapidly, high temperatures can be reached when fine fuels are available (Table 3). White et al. [46] reported that temperatures in grass fires could exceed $600{ }^{\circ} \mathrm{C}$, but would only last seconds. The short duration results in soil colors other than gray or orange. The base of larger bunch grasses can smolder, producing gray soils, but we did not see in the literature an observation of orange soils in this circumstance. Where dry, dead, and downed wood or dense shrubs occur, sustained high temperatures could result in pockets of gray ash or even orange char (categories 3.3 or 4.3 ) [5].

\subsection{Relating the PFI to Post-Fire Physical Soil Response}

To evaluate the effectiveness of the PFI in describing ecological conditions, we related our indicators to the physical, chemical, and biological responses noted in the literature. Common soil physical properties influenced by fire include water repellency, structure stability, texture, color, post-fire surface temperatures, and abundance of surface organic material [48] (Table 3). Typically erosion only occurs when organic cover is less than $40-50 \%$ after a fire [50-52,54]. Therefore, if slopes are steep 
and coarse textured soils are present, post-fire soil erosion is likely to occur in areas with PFI categories of 3.0 to 4.0. This range indicates water repellency is possible, especially on coarse textured soils and where gray ash is present $[50,89]$.

Heat and its duration can also change soil physical properties (Table 3). For example, when temperatures are between $200-450{ }^{\circ} \mathrm{C}$, soil structure stability decreases within a few minutes [48] and the combustion of organics can change particle size distribution [90]. The laterization process (i.e., when weathering causes depletion of soluble substances in soils and rocks) begins when soils are exposed to temperatures exceeding $450{ }^{\circ} \mathrm{C}$ for at least one hour [90]. From the reported interaction between soil heating, char color, and mineral soil appearance, one could infer that areas with soil PFI categories 2.0 through 4.0 may experience changes in soil physical properties (e.g., laterization, structural stability, or mineralogical changes) $[48,88,91]$.

\subsection{Relating the PFI to Post-Fire Soil Nutrients}

A soil's chemistry after a fire has an abundance of organic carbon, cation exchange capacity, and nutrient amounts and availability within the organic and surface mineral layers [48]. Soil nutrients are most abundant within the surface organic layers, upper mineral soil layers, and wood residue (brown cubical rotten wood and buried rotten wood). Harvey et al. [41] reported that in some forests up to $56 \%$ of the nitrogen occurs within the forest floor, surface mineral soil, and woody residue. During a fire, these components are vulnerable to loss through consumption and soil heating [93]. If gray ash is abundant and there is little to no surface organic layer remaining, a large portion of the total nitrogen may be absent (PFI category 4.3) [4]. However, if there is an abundance of surface organic material (PFI categories 1.0 and 2.0), and no gray- or orange-colored soils, [6,45,46], temperatures were insufficient to volatilize all the nitrogen [93]. Plant-available ammonium and nitrate can increase concomitantly with temperature and duration until they begin to volatilize [4,5], which most likely occurs on sites containing black-colored soils (PFI categories 2.1-2.3 and 3.1-3.3). As organic carbon is volatilized, concentrations of inorganic compounds such as potassium increase, although little change occurs with calcium [93]. Thus, in PFI categories 3.3 and 3.4 or 4.3 and 4.4 with gray or orange colored soils $[6,47]$ several inorganic elements would be abundant.

\subsection{Relating the PFI to Post-Fire Flora and Fauna Response}

Biological soil components sensitive to high temperatures include fungi, bacteria, soil-dwelling invertebrates, plant seed, roots, bulbs, root crowns, and other plant regenerative tissues [48]. Living organisms are negatively affected when temperatures exceed $40{ }^{\circ} \mathrm{C}$ [94]. Small mammals cannot survive temperatures exceeding $63{ }^{\circ} \mathrm{C}[95,96]$ and wingless insects die when exposed to temperatures greater than $40{ }^{\circ} \mathrm{C}$ [97]. Pollen, seeds, spores, lichens, and mosses cannot survive temperatures above $140{ }^{\circ} \mathrm{C}$ for more than 30 minutes [94]. Thus, above a PFI category of 2.3, there are limited amounts of soil flora or fauna present, except in the deeper mineral soils, or in areas where the heat has sufficiently dissipated. 


\subsection{Field Validation of Soil}

To evaluate the PFI's effectiveness for characterizing diverse outcomes after fires, we examined data from 950 plots distributed across 77 wildfires occurring in temperate conifer forests. We post-classified field measurements of the proportion of organic cover into our PFI categories (Figure 1a). Each surface organic category was further separated by mineral soil color and/or char. These data contained few observations with orange-colored mineral soil (categories 3.4 or 4.4), but several observations contained gray ash (Figure 1b). Conceptually, as heat and its residence time increases, more gray ash should appear and less surface organic material should be present [4,5]. Gray ash was present in all categories, with abundance increasing as surface organic material decreased.

Figure 1. For the 950 plots, the $25 \%$ and $75 \%$ quartiles (box bottom and top), confidence level (hour-glass), median (center dot), range (upper and lower T-bars), and outliers (dots) are displayed for percent surface organic matter cover (a) and percent grey colored mineral soil (b) by post-fire index (PFI) category.
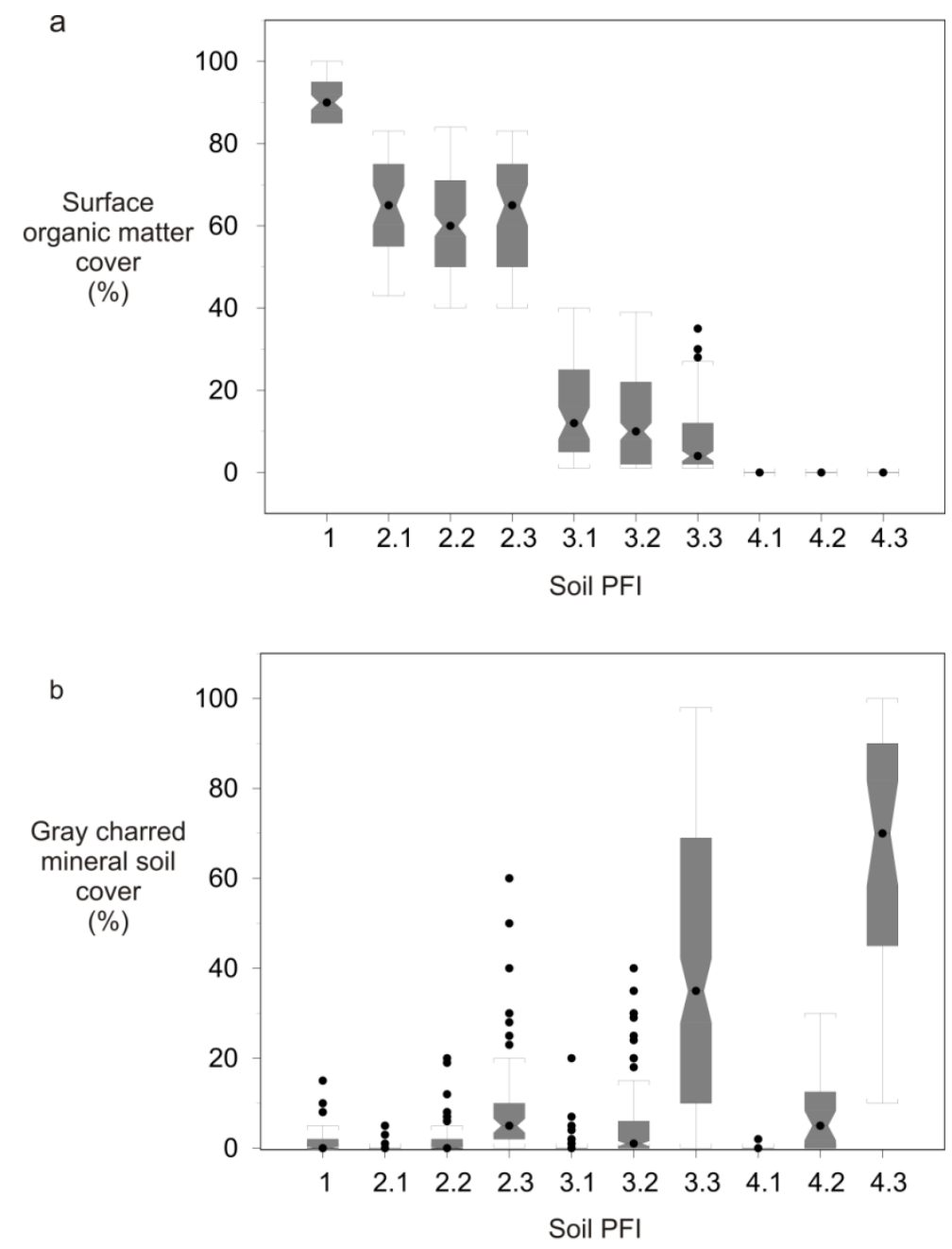

The amount of organic matter cover is the primary indicator used to separate the PFI categories and there is minimal overlap among the four broad categories (Figure 1a). Although the gray-charred mineral soil can occur within all categories, it dominates PFI category 3.3 and 4.3 (Figure 1b). This finding confirms the rational of using plurality when describing the post-fire environment. In the 
wildfires we sampled, we did not identify a condition where a plurality of orange-charred soil occurred on the plot; thus the reason for a lack of categories 2.4, 3.4 and 4.4.

\subsection{Ecological Implications and Management Applications}

Our soil post-fire index is intended to provide an ecological rationale for classifying the post-fire environment to improve understanding and interpretive value, and to inform a variety of research questions and management decisions. Moreover, the PFI was also developed to integrate multiple studies to increase the relevance, scope and impact of individual studies. To illustrate the relationship between the PFI and commonly used severity classifications we compared a select set of severity classification to the PFI (Table 4). Landscape assessments such as the Composite Burn Index (CBI) [8] and Burned Area Emergency Response (BAER) [9] are specifically designed to validate remotely sensed data. By separating the soils portion of CBI, our PFI can complement the initial broad classes of the CBI $(0.5-1 ; 1.5$ and 2.0, 2.5 and 3.0). Although the classification by Parsons et al. [9] was designed explicitly for BAER, maps created from this process are often used to fulfill other objectives. Our broad PFI categories (2.0, 3.0 and 4.0) complement the BAER categories. If further dissection of these broad categories is needed, the soil PFI allows for that flexibility.

Table 4. We compare the soil PFI to other assessments of severity. Using a subset of the literature displayed in Table 1 we illustrate how the PFI relates to other fire or burn severities. Each subject area includes the following: the publication, application, number of categories identified, and range of possible post-fire outcomes. Different colors (e.g., green to red) indicate the included categories while non-colored cells (---) denote an outcome that was not included. Post-fire characteristics most noted had two primary indicators. First, the amount of pre-fire surface organic matter (e.g., litter, humus, rotten wood) present, expressed as abundant, present, or absent on the forest floor. Second, whether the litter was scorched (S) and the state of the exposed mineral soil: unburned (U), blackened from combustion (B), gray/white (G) from ash, or orange (O) from mineralogical changes. The soil PFI is the last line.

\begin{tabular}{|c|c|c|c|c|c|c|c|c|c|c|c|c|c|c|c|c|}
\hline \multirow[b]{4}{*}{ Reference } & \multirow[b]{4}{*}{ Application } & \multirow{4}{*}{$\begin{array}{c}\text { Number of } \\
\text { categories }\end{array}$} & \multicolumn{14}{|c|}{ Post-fire—soils characteristic } \\
\hline & & & \multirow{3}{*}{$\begin{array}{l}\text { Un- } \\
\text { burned }\end{array}$} & \multicolumn{13}{|c|}{ Forest floor } \\
\hline & & & & \multicolumn{5}{|c|}{ Abundant } & \multicolumn{4}{|c|}{ Present } & \multicolumn{4}{|c|}{ Absent } \\
\hline & & & & $\mathrm{S}$ & $\mathbf{U}$ & B & $\mathbf{G}$ & $\mathbf{O}$ & $\mathbf{U}$ & \begin{tabular}{|l|l|}
$\mathbf{B}$ & \\
\end{tabular} & $\mathbf{G}$ & $\mathbf{O}$ & $\mathbf{U}$ & \begin{tabular}{|l|l}
$\mathbf{B}$ \\
\end{tabular} & $\mathbf{G}$ & $\mathbf{O}$ \\
\hline \multicolumn{17}{|c|}{ Physical effects } \\
\hline [9] & Values at risk & 3 & --- & & & & & & & & & & & & & \\
\hline \multicolumn{17}{|c|}{ Assessment } \\
\hline [8] & Remote sensing & 4 & & & & & & & & & & & & & & \\
\hline [77] & Monitoring & 5 & & & & & & & & & & & & & & \\
\hline [7] & Prescribed fire & 4 & & & & & & & & & & & & & & \\
\hline [39] & \begin{tabular}{|l|} 
Monitoring \\
\end{tabular} & 5 & & & & & & & & & -- & -- & & & & \\
\hline [39] (grasslands) & Monitoring & 5 & & & & & & & & & & & & & & -- \\
\hline \multirow[b]{2}{*}{ Soil PFI } & \multirow[b]{2}{*}{ Integrated index } & 5 & 0.0 & 1.0 & \multicolumn{4}{|c|}{2.0} & \multicolumn{4}{|c|}{3.0} & \multicolumn{4}{|c|}{4.0} \\
\hline & & 12 & 0.0 & 1.0 & 2.1 & \begin{tabular}{|l|l|l}
2.2 & 2 \\
\end{tabular} & 2.3 & 2.4 & 3.1 & \begin{tabular}{|l|l}
3.2 & 3 \\
\end{tabular} & 3.3 & 3.4 & 4.1 & 4.2 & 4.3 & 4.4 \\
\hline
\end{tabular}


Table 4. Cont.

\begin{tabular}{|c|c|c|c|c|c|c|c|c|c|c|c|c|c|c|c|c|}
\hline \multirow[b]{4}{*}{ Reference } & \multirow[b]{4}{*}{ Application } & \multirow{4}{*}{$\begin{array}{c}\text { Number of } \\
\text { categories }\end{array}$} & \multicolumn{14}{|c|}{ Post-fire-soils characteristic } \\
\hline & & & \multirow{3}{*}{$\begin{array}{l}\text { Un- } \\
\text { burned }\end{array}$} & \multicolumn{13}{|c|}{$\begin{array}{c}\text { Forest floor } \\
\end{array}$} \\
\hline & & & & \multicolumn{5}{|c|}{ Abundant } & \multicolumn{4}{|c|}{ Present } & \multicolumn{4}{|c|}{ Absent } \\
\hline & & & & $\mathrm{S}$ & $\mathbf{U}$ & $\mathbf{B}$ & $\mathbf{G}$ & $\mathbf{O}$ & $\mathbf{U}$ & $\mathbf{B}$ & $\mathbf{G}$ & $\mathbf{O}$ & $\mathbf{U}$ & $\mathbf{B}$ & G & $\mathbf{O}$ \\
\hline \multicolumn{17}{|c|}{ Literature review } \\
\hline [5] (forests) & Soil effects & 3 & --- & & & & & & & & & & & & & \\
\hline 5 (grassland) & Soil effects & 3 & --- & & & & & & & & & & & & & --- \\
\hline 3 & Soil effects & 3 & --- & & & & & & & & & & & & & \\
\hline \multirow[b]{2}{*}{ Soil PFI } & \multirow[b]{2}{*}{ Integrated index } & 5 & 0.0 & 1.0 & \multicolumn{4}{|c|}{2.0} & \multicolumn{4}{|c|}{3.0} & \multicolumn{4}{|c|}{4.0} \\
\hline & & 12 & 0.0 & 1.0 & 2.1 & 2.2 & 2.3 & 2.4 & 3.1 & 3.2 & 3.3 & 3.4 & 4.1 & 4.2 & 4.3 & 4.4 \\
\hline
\end{tabular}

We designed our PFI as a nested classification. Many other fire characterizations do not have this option, using instead a general description that can be difficult to replicate. We based our PFI categories on two main criteria: (1) the condition of surface organic matter to identify general broad categories; and (2) mineral soil color to narrow the broad categories and create simple and repeatable classifications. The soil PFI is less complex than Ryan and Noste [7] who use a series of observable descriptions to partition the post-prescribed fire characterization (Table 4). Their qualitative method may introduce inconsistencies depending on the skill of the individual conducting the assessment. When we developed our PFI we recognized the high value of Ryan and Noste [7] and extended their concepts to create a more parsimonious index for the two areas that consistently differed in their classification; namely, surface organic matter (litter and duff) and mineral soil color.

Assigning PFI categories is best conducted either immediately after the fire or early in the following growing season. The appropriate time to quantify the post-fire environment is a function of the objectives and feasibility of acquiring the data. If quantifying soil erosion is of interest, then assigning PFI categories immediately after combustion ends may be required [49]. If estimating the potential for tree seedling regeneration is the objective, then sampling during the year following the fire is more appropriate because snowfall or rain may move soil or ash containing seeds. Assigning soil PFI categories becomes more difficult after the first growing season because surface vegetation obscures mineral soil color or residual surface organic material.

Information objectives, site variability, appropriate spatial scale, and other fundamental sampling protocols must be considered before developing a sampling design and frame for determining the PFI category [98]. Therefore, we do not provide a specific sampling design or unit size. CBI [8] uses a plot size appropriate for remotely sensed data $\left(10 \mathrm{~m}^{2}\right)$. A similar plot could be used to assign PFI categories and could thus be readily related to remotely sensed data. For those who are unsure of the appropriate sampling protocols, we suggest referring to the many sources available that discuss sampling methods associated with multi-resource forest inventories [98,99].

\section{Conclusions}

Our goal was to provide a classification system to aid investigators and managers interested in describing what is left after a fire - one that provides ecological interpretation and future predictability. Our PFI is a method to predict post-fire responses, rate of plant recovery, microbial habitat, and 
address post-fire monitoring needs. It is designed to focus on what remains after a fire, which could be considered a type of severity indicator, but it is not intended to describe fire characteristics (fire severity) or degree of change (burn severity). The PFI was developed to complement these classifications and provide a means to integrate different perspectives of the fire continuum. Thus, at times we used burn or fire severity indicators similar to what others have used (e.g., soil color). In doing so, we hope to provide understanding to the many benefits and consequences of fire. To better meet these different perspectives, we also encourage the use of auxiliary variables we identified to customize the PFI. By conducting the synthesis following a literature evaluation, we ascertained the science and ecological rationale for the particular PFI categories. Through future replicated experiments, the thresholds we selected can be further validated and the interpretative and predictive value of the PFI substantiated. We consider the PFI presented here as a foundation for future investigations and foresee their application as another step towards gaining a more comprehensive understanding of post-fire environments and subsequent ecosystem responses.

In addition to use by scientists, the PFI provides a method for managers to help inform management decisions. It can be used as a monitoring and communications tool, or as a way to describe desired future conditions. Therefore, the PFI could help to develop post-fire management strategies and set rehabilitation priorities. For example, interpretation from the PFI categories could provide information to develop strategies for protecting wildlife habitat and reducing future fire hazard. As mentioned in the introduction, the PFI can be an integral component for any silvicultural system designed to manage burned forests or implement fuel treatments.

\section{Acknowledgements}

The authors thank Michael Ryan, Robert Keane, Kathleen Dwire, and Kristen Meyer, who gave their time and provided invaluable comments during the preparation of the manuscript. In addition, we thank the many people who provided their ideas, comments, and concerns during the process of developing the indices, resulting in considerable thought and discussion which led to the PFIs we present. Most importantly we thank the referees for their thoughtful and thorough reviews. The funding from this work was provided by National Fire Plan Funding and was distributed through the United States Department of Agriculture, Forest Service, Rocky Mountain Research Station.

\section{Conflict of Interest}

The authors declare no conflict of interest.

\section{References}

1. Millennium Ecosystem Assessment. Synthesis; Island Press: Washington, DC, USA, 2005.

2. Jain, T.B.; Graham, R.T.; Pilliod, D.S. Tongue-tied. Wildfire 2004, July/August, 2-6.

3. Wells, C.G.; Campbell, R.E.; DeBano, L.F.; Lewis, C.E.; Fredriksen, R.L.; Franklin, E.C.; Froelich, R.C.; Dunn, P.H. Effects of Fire on Soil: A State-of-Knowledge Review; General Technical Report WO-7; USDA Forest Service: Washington, DC, USA, 1979. 
4. Hungerford, R.D.; Harrington, M.G.; Frandsen, W.H.; Ryan, K.C.; Niehoff, G.J. Influence of Fire on Factors That Affect Site Productivity. In Proceedings-Management and Productivity of Western-montane Forest Soils; Harvey, A.E., Neuenschwander, L.F., Comps.; General Technical Report INT-GTR-280; USDA Forest Service, Intermountain Research Station: Ogden, UT, USA, 1991; pp. 32-50.

5. DeBano, L.F.; Neary, D.G.; Ffolliott, P.F. Fire: Its Effect on Soil and Other Ecosystem Resources; John Wiley \& Sons, Inc.: New York, NY, USA, 1998.

6. Wondafrash, T.T.; Sancho, I.M.; Miguel, V.G.; Serrano, R.E. Relationship between soil color and temperature in the surface horizon of Mediterranean soils: A laboratory study. Soil Sci. 2005, 170, 495-503.

7. Ryan, K.C.; Noste, N.V. Evaluating Prescribed Fires. In Proceedings_Symposium and Workshop on Wilderness Fire; Lotan, J.E., Kilgore, B.M., Fischer, W.C., Mutch, R.W., Eds.; General Technical Report INT-182; USDA Forest Service, Intermountain Forest and Range Experiment Station: Ogden, UT, USA, 1985; pp. 230-238.

8. Key, C.H.; Benson, N.C. Landscape Assessment: Ground Measure of Severity, the Composite Burn Index; and Remote Sensing of Severity, the Normalized Burn Ratio. In FIREMON: Fire Effects Monitoring and Inventory System; Lutes, D.C., Keane, K.E., Caratti, J.F., Key, C.H., Benson, N.C., Sutherland, S., Gangi, L.J., Eds.; General Technical Report RMRS-GTR-164-CD; USDA Forest Service, Rocky Mountain Research Station: Fort Collins, CO, USA, 2006.

9. Parsons, A.; Robichaud, P.R.; Lewis, S.A.; Napper, C.; Clark, J.T. Field Guide for Mapping Post-Fire Soil Burn Severity; General Technical Report RMRS-GTR-243; USDA Forest Service, Rocky Mountain Research Station: Fort Collins, CO, USA, 2010.

10. Keeley, J.E. Fire intensity, fire severity and burn severity: A brief review and suggested usage. Int. J. Wildland Fire 2009, 18, 116-126.

11. Jain, T.B.; Graham, R.T. The Relation between Tree Burn Severity and Forest Structure in the Rocky Mountains. In Proceedings of the 2005 National Silviculture Workshop on Restoring Fire-Adapted Ecosystems, Tahoe City, CA, USA, 6-10 June 2005; Powers, R.F., Ed.; General Technical Report PSW-GTR-203; USDA Forest Service, Pacific Southwest Research Station: Albany, CA, USA, 2007; pp. 213-250.

12. Jain, T.B.; Gould, W.; Graham, R.T.; Pilliod, D.S.; Lentile, L.B.; Gonzalez, G. A soil burn severity index for understanding soil-fire relations in tropical forests. Ambio 2008, 37, 563-568.

13. Fraver, S.; Jain, T.B.; Bradford, J.B.; D’Amato, A.W.; Kastendick, D.; Palik, B.; Shinneman, D.; Stanovick, J. The efficacy of salvage logging in reducing subsequent fire severity in conifer-dominated forests of Minnesota, USA. Ecol. Appl. 2011, 21, 1895-1901.

14. Keeley, J.E.; Fotheringham, C.J.; Baer-Keeley, M. Factors affecting plant diversity during post-fire recovery and succession of mediterranean-climate shrublands in California, USA. Divers. Distrib. 2005, 11, 525-537.

15. Langlands, P.R.; Brennan, K.E.C.; Framenau, V.W.; Main, B.Y. Predicting the post-fire responses of animal assemblages: Testing a trait-based approach using spiders. J. Anim. Ecol. 2011, 80, 558-568.

16. Santana, V.M.; Baeza, M.J.; Maestre, F.T. Seedling establishment along post-fire succession in Mediterranean shrublands dominated by obligate seeders. Acta Oecol. 2012, 39, 51-60. 
17. Smith, J.K.; Fischer, W.C. Fire Ecology of the Forest Habitat Types of Northern Idaho; General Technical Report INT-GTR-363; USDA Forest Service, Intermountain Research Station: Ogden, UT, USA, 1997.

18. Helms, J.A. The Dictionary of Forestry; Society of American Foresters: Bethesda, MD, USA, 1998.

19. Graham, R.T.; Harvey, A.E.; Jain, T.B.; Tonn, J.R. The Effects of Thinning and Similar Stand Treatments on Fire Behavior in Western Forests; General Technical Report PNW-GTR-463; USDA Forest Service, Pacific Northwest Research Station: Portland, OR, USA, 1999.

20. Reynolds, R.T.; Graham, R.T.; Reiser, M.H.; Bassett, R.L.; Kennedy, P.L.; Boyce, D.A.; Goodwin, G., Jr.; Smith, R.; Fisher, E.L. Management Recommendations for the Northern Goshawk in the Southwestern United States; General Technical Report RM-217; USDA Forest Service, Rocky Mountain Forest and Range Experiment Station: Fort Collins, CO, USA, 1992.

21. Pilliod, D.S.; Bull, E.L.; Hayes, J.L.; Wales, B.C. Wildlife and Invertebrate Response to Fuel Reduction Treatments in Dry Coniferous Forests of the Western United States: A Synthesis; General Technical Report RMRS-GTR-173; USDA Forest Service, Rocky Mountain Research Station: Fort Collins, CO, USA, 2006.

22. Jurgensen, M.F.; Harvey, A.E.; Graham, R.T.; Page-Dumroese, D.S.; Tonn, J.R.; Larsen, M.J.; Jain, T.B. Impacts of timber harvesting on soil organic matter, nitrogen, productivity, and health of inland northwest forests. For. Sci. 1997, 43, 234-251.

23. Page-Dumroese, D.; Jurgensen, M.; Elliot, W.; Rice, T.; Nesser, J.; Collins, T.; Meurisse, R. Soil quality standards and guidelines for forest sustainability in northwestern North America. For. Ecol. Manag. 2000, 138, 445-462.

24. Schoenholtz, S.H.; van Miegroet, H.; Burger, J.A. A review of chemical and physical properties as indicators of forest soil quality: Challenges and opportunities. For. Ecol. Manag. 2000, 138, 335-356.

25. Canadell, J.G.; Raupach, M.R. Managing forests for climate change mitigation. Science 2008, 320, 1456-1457.

26. Pullin, A.S.; Stewart, G.B. Guidelines for systematic review in conservation and management. Conserv. Biol. 2006, 20, 1647-1656.

27. SAS, version 9.2; software; SAS Institute Inc.: Cary, NC, USA, 2002-2008; 27513.

28. Graham, R.T.; Jain, T.B.; Loseke, M. Fuel Treatments, Fire Suppression, and Their Interaction with Wildfire and Its Impacts: The Warm Lake Experience During the Cascade Complex of Wildfires in Central Idaho, 2007; General Technical Report RMRS-GTR-229; USDA Forest Service, Rocky Mountain Research Station: Fort Collins, CO, USA, 2009.

29. Jain, T.B.; Juillerat, M.; Sandquist, J.; Ford, M.; Sauer, B.; Mitchell, R.; McAvoy, S.; Hanley, J.; David, J. Photograph Handbook for Comparing Burned and Unburned Sites Within a Dry Forested and Grassland Mosaic: A Tool for Communication, Calibration, and Monitoring Post-Fire Effects; General Technical Report RMRS-GTR-197; USDA Forest Service, Rocky Mountain Research Station: Fort Collins, CO, USA, 2007.

30. Baird, M.; Zabowski, D.; Everett, R.L. Wildfire effects on carbon and nitrogen in inland coniferous forests. Plant Soil 1999, 209, 233-243. 
31. Dress, W.J.; Boerner, R.E.J. Temporal and spatial patterns in root nitrogen concentration and root decomposition in relation to prescribed fire. Am. Midl. Nat. 2003, 149, 245-257.

32. Dyrness, C.T.; Norum, R.A. The effects of experimental fires on black spruce forest floors in interior Alaska. Can. J. For. Res. 1983, 13, 879-893.

33. Morgan, P.; Neuenschwander, L.F. Seed-bank contributions to regeneration of shrub species after clear-cutting and burning. Can. J. Bot. 1988, 66, 169-172.

34. Brais, S.; Pare, D.; Ouimet, R. Impacts of wild fire severity and salvage harvesting on the nutrient balance of jack pine and black spruce boreal stands. For. Ecol. Manag. 2000, 137, 231-243.

35. White, J.D.; Ryan, K.C.; Key, C.C.; Running, S.W. Remote sensing of forest fire severity and vegetation recovery. Int. J. Wildland Fire 1996, 6, 125-136.

36. Wang, G.G.; Kemball, K.J. Effects of fire severity on early development of understory vegetation. Can. J. For. Res. 2005, 35, 254-262.

37. Alexander, J.D.; Seavy, N.E.; Ralph, J.C.; Hogoboom, B. Vegetation and topographical correlates of fire severity from two fires in the Klamath-Siskiyou region of Oregon and California. Int. J. Wildland Fire 2006, 15, 237-245.

38. Patterson, M.W.; Yool, S.R. Mapping fire-induced vegetation mortality using Landsat Thematic Mapper data: A comparison of linear transformation techniques. Remote Sens. Environ. 1998, 65, $132-142$.

39. USDI. Fire Monitoring Handbook; Fire Management Program Center, National Interagency Fire Center: Boise, ID, USA, 2003.

40. Murphy, J.D.; Johnson, D.W.; Miller, W.W.; Walker, R.F.; Blank, R.R. Prescribed fire effects on forest floor and soil nutrients in a Sierra Nevada Forest. Soil Sci. 2006, 171, 181-199.

41. Harvey, A.E.; Jurgensen, M.F.; Larsen, M.J.; Graham, R.T. Relationships among soil microsite, ectomycorrhizae, and natural conifer regeneration of old-growth forests in western Montana. Can. J. For. Res. 1987, 17, 58-62.

42. Kasischke, E.S.; Johnstone, J.F. Variation in postfire organic layer thickness in a black spruce forest complex in interior Alaska and its effects on soil temperature and moisture. Can. J. For. Res. 2005, 35, 2164-2177.

43. Neary, D.G.; Ryan, K.C.; DeBano, L.F. Wildland Fire in Ecosystems: Effects of Fire on Soils and Water; General Technical Report RMRS-GTR-42; USDA Forest Service, Rocky Mountain Research Station: Ogden, UT, USA, 2005; Volume 4.

44. Neary, D.G.; Klopatek, C.C.; DeBano, L.F.; Ffolliott, P.F. Fire effects on belowground sustainability: A review and synthesis. For. Ecol. Manag. 1999, 122, 51-71.

45. Bentley, J.R.; Fenner, R.L. Soil temperatures during burning related to postfire seedbeds on woodland range. J. For. 1958, 56, 737-740.

46. White, E.M.; Thompson, W.W.; Gartner, F.R. Heat effects on nutrient release from soils under ponderosa pine. J. Range Manag. 1973, 26, 22-24.

47. Ketterings, Q.M.; Bigham, J.M. Soil color as an indicator of slash-and-burn fire severity and soil fertility in Sumatra, Indonesia. Soil Sci. Soc. Am. J. 2000, 64, 1826-1833.

48. Certini, G. Effects of fire on properties of forest soils: A review. Oecologia 2005, 143, 1-10.

49. Robichaud, P.R. Fire effects on infiltration rates after prescribed fire in Northern Rocky Mountain forests, USA. J. Hydrol. 2000, 231-232, 220-229. 
50. Lewis, S.A.; Wu, J.Q.; Robichaud, P.R. Assessing burn severity and comparing soil water repellency, Hayman Fire, Colorado. Hydrol. Process. 2006, 20, 1-16.

51. Johansen, M.P.; Hakonson, T.E.; Breshears, D.D. Post-fire runoff and erosion from rainfall simulation: Contrasting forests with shrublands and grasslands. Hydrol. Process. 2001, 15, 2953-2965.

52. Pannkuk, C.D.; Robichaud, P.R. Effectiveness of needle cast at reducing erosion after forest fires. Water Resour. Res. 2003, 39, 1333-1344.

53. Meeuwig, R.O. Infiltration and Soil Erosion on Coolwater Ridge, Idaho; Research Note INT-RN-103; USDA Forest Service, Intermountain Forest and Range Experiment Station: Ogden, UT, USA, 1969.

54. Benavides-Solorio, J.; MacDonald, L.H. Post-fire runoff and erosion from simulated rainfall on small plots, Colorado Front Range. Hydrol. Process. 2001, 15, 2931-2952.

55. Miller, M. Fire Behavior and Characteristics. In Fire Effects Guide; Miller, M., Ed.; National Interagency Fire Center: Boise, ID, USA, 2001; pp. 12-38.

56. Neff, J.C.; Harden, J.W.; Gleixner, G. Fire effects on soil organic matter content, composition, and nutrients in boreal interior Alaska. Can. J. For. Res. 2005, 35, 2178-2187.

57. Shakesby, R.A.; Chafer, C.J.; Doerr, S.H.; Blake, W.H.; Wallbrink, P.; Humphreys, G.S.; Harrington, B.A. Fire severity, water repellency characteristics and hydrogeomorphological changes following the Christmas 2001 Sydney forest fires. Aust. Geogr. 2003, 34, 147-175.

58. Ulery, A.L.; Graham, R.C. Forest fire effects on soil color and texture. Soil Sci. Soc. Am. J. 1993, 57, 135-140.

59. Arocena, J.M.; Opio, C. Prescribed fire-induced changes in properties of sub-boreal forest soils. Geoderma 2003, 113, 1-16.

60. Cerri, C.C.; Volkoff, B.; Andreaux, F. Nature and behaviour of organic matter in soils under natural forest, and after deforestation, burning, and cultivation, near Manaus. For. Ecol. Manag. 1991, 38, 247-257.

61. Ellingson, L.J.; Kauffman, J.B.; Cummings, D.L.; Sanford, R.L., Jr.; Jaramillo, V.J. Soil N dynamics associated with deforestation, biomass burning, and pasture conversion in a Mexican tropical dry forest. For. Ecol. Manag. 2000, 137, 41-51.

62. Prieto-Fernández, Á.; Carballas, M.; Carballas, T. Inorganic and organic $\mathrm{N}$ pools in soils burned or heated: Immediate alterations and evolution after forest wildfires. Geoderma 2004, 121, 291-306.

63. Rumpel, C.; González-Pérez, J.A.; Bardoux, G.; Largeau, C.; Gonzalez-Vila, F.J.; Valentin, C. Composition and reactivity of morphologically distinct charred materials left after slash-and-burn practices in agricultural tropical soils. Org. Geochem. 2007, 38, 911-920.

64. Yeager, C.M.; Northup, D.E.; Grow, C.C.; Barns, S.M.; Kuske, C.R. Changes in nitrogen-fixing and ammonia-oxidizing bacterial communities in soil of a mixed conifer forest after wildfire. Appl. Environ. Microb. 2005, 71, 2713-2722.

65. Bellgard, S.E.; Whelan, R.J.; Muston, R.M. The impact of wildfire on vesicular-arbuscular Mycorrhizal fungi and their potential to influence the re-establishment of post-fire plant communities. Mycorrhiza 1994, 4, 139-146. 
66. Horton, T.R.; Cázares, E.; Bruns, T.D. EctoMycorrhizal, vesicular-arbuscular and dark septate fungal colonization of bishop pine (Pinus muricata) seedlings in the first 5 months of growth after wildfire. Mycorrhiza 1998, 8, 11-18.

67. Bernhardt, E.L.; Hollingsworth, T.N.; Chapin, I.F.S. Fire severity mediates climate-driven shifts in understory community composition of black spruce stands of interior Alaska. J. Veg. Sci. 2011, 22, 32-44.

68. Blank, R.R.; Allen, F.; Young, J.A. Extractable anions in soils following wildfire in a sagebrush-grass community. Soil Sci. Soc. Am. J. 1994, 58, 564-570.

69. Tyler, C.M. Factors contributing to postfire seedling establishment in chaparral: Direct and indirect effects of fire. J. Ecol. 1995, 83, 1009-1020.

70. Bonnet, V.H.; Schoettle, A.W.; Shepperd, W.D. Postfire environmental conditions influence the spatial pattern of regeneration for Pinus ponderosa. Can. J. For. Res. 2005, 35, 37-47.

71. Choromanska, U.; DeLuca, T.H. Microbial activity and nitrogen mineralization in forest mineral soils following heating: Evaluation of post-fire effects. Soil Biol. Biochem. 2002, 34, 263-271.

72. Cromack, K., Jr.; Landsberg, J.D.; Everett, R.L.; Zeleny, R.; Giardina, C.P.; Strand, E.K.; Anderson, T.D.; Averill, R.; Smyrski, R. Assessing the impacts of severe fire on forest ecosystem recovery. J. Sustain. For. 2000, 11, 177-228.

73. Jain, T.B.; Graham, R.T.; Pilliod, D.S. The Relation between Forest Structure and Soil Burn Severity. In Fuels Management-How to Measure Success: Conference Proceedings RMRS-P-41, 28-30 March 2006; Portland, OR, USA; Andrews, P.L., Butler, B.W., Comps.; USDA Forest Service, Rocky Mountain Research Station: Fort Collins, CO, USA, 2006; pp. 615-631.

74. Larrivée, M.; Fahrig, L.; Drapeau, P. Effects of a recent wildfire and clearcuts on ground-dwelling boreal forest spider assemblages. Can. J. For. Res. 2005, 35, 2575-2588.

75. Lentile, L.B.; Smith, F.W.; Shepperd, W.D. Patch structure, fire-scar formation, and tree regeneration in a large mixed-severity fire in the South Dakota Black Hills, USA. Can. J. For. Res. 2005, 35, 2875-2885.

76. Schimmel, J.; Granstrom, A. Fire severity and vegetation response in the boreal Swedish forest. Ecology 1996, 77, 1436-1450.

77. Lutes, D.C.; Keane, R.E.; Caratti, J.F.; Key, C.H.; Benson, N.C.; Sutherland, S.; Gangi, L.J. FIREMON: Fire Effects Monitoring and Inventory System; General Technical Report RMRS-GTR-164-CD; USDA Forest Service, Rocky Mountain Research Station: Fort Collins, CO, USA, 2006.

78. Barkley, Y.C. After the Burn: Assessing and Managing your Forestland After a Wildfire; Idaho Forest, Wildlife and Range Experiment Station Bulletin No. 76; University of Idaho Extension: Moscow, ID, USA, 2006.

79. Chafer, C.J.; Noonan, M.; Macnaught, E. The post-fire measurement of fire severity and intensity in the Christmas 2001 Sydney wildfires. Int. J. Wildland Fire 2004, 13, 227-240.

80. Fischer, W.C.; Clayton, B.D. Fire Ecology of Montana Forest Habitat Types East of the Continental Divide; General Technical Report INT-141; USDA Forest Service, Intermountain Forest and Range Experiment Station: Ogden, UT, USA, 1983.

81. Eyre, F.H. Forest Cover Types of the United States and Canada; Society of American Foresters: Washington, DC, USA, 1980. 
82. Haig, I.T.; Davis, K.P.; Weidman, R.H. Natural Regeneration in the Western White Pine Type; Technical Bulletin 767; U.S. Department of Agriculture: Washington, DC, USA, 1941.

83. Cochran, P.H. Thermal Properties and Surface Temperatures of Seedbeds: A Guide for Foresters; USDA Forest Service, Pacific Northwest Forest and Range Experiment Station: Portland, OR, USA, 1969.

84. Wright, H.A.; Bailey, A.W. Fire Ecology: United States and Southern Canada; John Wiley \& Sons: New York, NY, USA, 1982.

85. Agee, J.K. Fire Ecology of Pacific Northwest Forests; Island Press: Washington, DC, USA, 1993.

86. Robichaud, P.R.; Graham, R.T.; Hungerford, R.D. Onsite Sediment Production and Nutrient Losses from a Low-severity Burn in the Interior Northwest. In Interior Cedar-Hemlock-White Pine Forests: Ecology and Management: Symposium Proceedings; Baumgartner, D.M., Lotan, J.E., Tonn, J.R., Eds.; Washington State University: Pullman, WA, USA, 1994; pp. 227-232.

87. Boyer, D.E.; Dell, J.D. Fire Effects on Pacific Northwestern Soils; USDA Forest Service, Pacific Northwest Region, Watershed Management and Aviation and Fire Management: Portland, OR, USA, 1980.

88. Ketterings, Q.M.; Bigham, J.M.; Laperche, V. Changes in soil mineralogy and texture caused by slash-and-burn fires in Sumatra, Indonesia. Soil Sci. Soc. Am. J. 2000, 64, 1108-1117.

89. DeBano, L.F.; Rice, R.M.; Conrad, C.E. Soil Heating in Chaparral Fires: Effects on Soil Properties, Plant Nutrients, Erosion, and Runoff; Research Paper PSW-145; USDA Forest Service, Pacific Southwest Forest and Range Experiment Station: Berkeley, CA, USA, 1979.

90. Giovannini, G.; Lucchesi, S. Modifications induced in soil physico-chemical parameters by experimental fires at different intensities. Soil Sci. 1997, 162, 479-486.

91. Ulery, A.L.; Graham, R.C.; Bowen, L.H. Forest fire effects on soil phyllosilicates in California. Soil Sci. Soc. Am. J. 1996, 60, 309-315.

92. Hood, S.M. Mitigating Old Tree Mortality in Long-unburned, Fire-Dependent Forests: A Synthesis; General Technical Report RMRS-GTR-238; USDA Forest Service, Rocky Mountain Research Station: Fort Collins, CO, USA, 2010.

93. Guerrero, C.; Mataix-Solera, J.; Gómez, I.; García-Orenes, F.; Jordán, M.M. Microbial recolonization and chemical changes in a soil heated at different temperatures. Int. J. Wildland Fire 2005, 14, 385-400.

94. Levitt, J. Responses of Plants to Environmental Stress. Vol. 1, Chilling, Freezing, and High Temperature Stresses; Academic Press: New York, NY, USA, 1980.

95. Howard, W.E.; Fenner, R.L.; Childs, H.E., Jr. Wildlife survival in brush burns. J. Range Manag. 1959, 12, 230-234.

96. Lyon, L.J.; Telfer, E.S.; Schreiner, D.S. Direct Effects of Fire and Animal Responses. In Wildland Fire in Ecosystems: Effects of Fire on Fauna; Smith, J.K., Ed.; General Technical Report RMRS-GTR-42; USDA Forest Service, Rocky Mountain Research Station: Ogden, UT, USA, 2000; Volume 1, pp. 17-24.

97. Christiansen, K. Bionomics of collembola. Annu. Rev. Entomol. 1964, 9, 147-178.

98. Köhl, M.; Magnussen, S.S.; Marchetti, M. Sampling Methods, Remote Sensing and GIS Multiresource Forest Inventory; Springer: Berlin, Germany, 2006. 
99. Schreuder, H.T.; Gregoire, T.G.; Wood, G.B. Sampling Methods for Multiresource Forest Inventory; John Wiley \& Sons, Inc: New York, NY, USA, 1993.

(C) 2012 by the authors; licensee MDPI, Basel, Switzerland. This article is an open access article distributed under the terms and conditions of the Creative Commons Attribution license (http://creativecommons.org/licenses/by/3.0/). 